\title{
PENGEMBANGAN MODEL PEMBELAJARAN TEMATIK INTEGRATIF PENJASORKES PADA MATA PELAJARAN ILMU PENGETAHUAN ALAM DI SEKOLAH DASAR
}

\author{
Giartama $^{1)}$ Hartati $^{2)}$, Destriani $^{3)}$, dan Ahmad Richard Victoriand ${ }^{4)}$ \\ 1,2,3,4 Pendidikan Jasmani dan Kesehatan, FKIP Universitas Sriwijaya \\ ${ }^{1,2,3,4} \mathrm{Jl}$. Palembang-Prabumulih, KM 32 Inderalaya, Kabupaten Ogan Ilir, 30662 \\ giartama58@gmail.com ${ }^{1)}$, hartati2@fkip.unsri.ac.id ${ }^{2)}$, destriani@fkip.unsri.ac.id ${ }^{3)}$, richarda@yahoo.com ${ }^{4)}$
}

\begin{abstract}
ABSTRAK
Penelitian ini bertujuan untuk mengembangkan model pembelajaran tematik integratif penjasorkes pada mata pelajaran IPA di sekolah dasar. Metode penelitian yang digunakan adalah research and development. Subjek uji coba skala kecil berasal dari satu sekolah dasar yang terdiri dari 1 orang guru penjasorkes dan 20 siswa, serta untuk subjek uji coba skala besar berasal dari dua sekolah dasar yang berbeda yang terdiri dari 2 orang guru penjasorkes dan 45 siswa. Data yang dikumpulkan dari penelitian ini berupa data kuantitatif. Data kuantitatif diperoleh dari: (a) penilaian skala nilai validasi; (b) angket guru penjaskes; , dan (c) nilai tes pengetahuan. Hasil penilaian untuk skala besar dari 1) Skala dari validasai ahli, yang pertama ahli materi pendidikan jasmani dan kesehatan dengan persentase nilai sebesar 74\% dan masuk pada kategori "layak" dan yang kedua ahli materi IPA anak sekolah dasar dengan persentase nilai 84\% masuk pada kategori "sangat layak", 2) Angket guru penjaskes dengan nilai rata-rata sebesar $81 \%$ sehingga masuk pada kategori "sangat layak", dan 3) Nilai tes pengetahuan siswa dengan rata-rata nilai 86,2. Hasil penelitian ini menunjukkan secara keseluruhan model pembelajaran tematik integratif ini layak digunakan untuk proses pembelajaran Penjasorkes di sekolah dasar. Implikasi penelitian ini adalah guru dapat menggunakan pengembangan model pembelajaran ini untuk variasi dalam mengajar, dan untuk siswa dapat menambah minat dalam mata pelajaran Penjasorkes.
\end{abstract}

Kata Kunci: Model Pembelajaran, Tematik Integratif, Penjasorkes, Sekolah Dasar

\section{PENDAhUluan}

Pendidikan jasmani menurut Rosdiani (2012) adalah proses pendidikan yang memanfaatkan aktivitas jasmani yang direncanakan secara sistematik bertujuan untuk mengembangkan dan meningkatkan individu secara organik, neuromoskuler, perseptual, kognitf, dan emosional dalam kerangka sistem pendidikan nasional. Pendidikan jasmani menurut Husdarta \& Kusmaedi (2011) adalah media untuk meraih tujuan pendidikan sekaligus juga untuk meraih tujuan yang bersifat internal ke dalam aktivitas fisik itu sendiri.

Dalam pembelajaran terdapat berbagai model pembelajaran yang masing-masing memiliki tujuan dan sasaran yang berbeda, sehingga seorang guru harus mampu menyesuaikan model yang digunakan dalam suatu pembelajaran. Lebih dari satu macam metode pembelajaran, gaya mengajar, maupun strategi pembelajaran dapat digunakan dalam satu model pembelajaran.

pendapat Joyce, Weil \& Calhoun (2009) model pembelajaran dapat digambarkan dimana saat kita membantu siswa memperoleh informasi, gagasan, skill, nilai, cara berpikir, dan tujuan mengekspresikan diri mereka sendiri, kita sebenarnya tengah mengajari mereka untuk belajar.
Berdasarkan hal tersebut mencoba untuk menciptakan suatu model pembelajaran dimana, model pembelajaran ini digunakan oleh guru sebagai panduan dalam pelaksanaan pembelajaran di sekolah. Model pembelajaran tersebut adalah model pembelajaran integratif, yang pada hakikatnya merupakan suatu pendekatan pembelajaran yang memungkinkan peserta didik baik secara individu maupun kelompok aktif mencari, menggali dan menemukan konsep serta prinsip secara holistik dan autentik (Trianto, 2014). Dalam menerapkan dan melaksanakan pembelajaran tematik, ada beberapa prinsip dasar yang perlu diperhatikan yaitu: (1) Bersifat kontekstual atau terintegrasi dengan lingkungan.Pembelajaran yang dilakukan perlu dikemas dalam suatu format keterkaitan, maksudnya pembahasan suatu topik dikaitkan dengan kondisi yang dihadapi siswa atau ketika siswa menemukan masalah dan memecahkan masalah yang nyata dihadapi siswa dalam kehidupan seharihari dikaitkan dengan topik yang dibahas. (2) Bentuk belajar harus dirancang agar siswa bekerja secara sungguh-sungguh untuk menemukan tema pembelajaran yang riil sekaligus mengaplikasikannya. Dalam melakukan pembelajaran tematik siswa didorong untuk mampu menemukan tema-tema yang benar-benar sesuai dengan kondisi siswa, bahkan 
dialami siswa. (3) Efisiensi Pembelajaran tematik memiliki nilai efisiensi antara lain dalam segi waktu, beban materi, metode, penggunaan sumber belajar yang otentik sehingga dapat mencapai ketuntasan kompetensi secara tepat.

Kurikulum 2013 yang menggunakan tematik integratif dalam pembelajaran maka pada mata pelajaran penjasorkes perlu dikembangkan pembelajaran tematik integratif. Untuk pelajaran penjasorkes dapat diintegrasikan pada berbagai mata pelajaran di sekolah dasar seperti agama, ipa, ips, ppkn, bahasa inggris dan lain-lain. Mata Pelajaran IPA memiliki komponen yang dapat diintegrasikan pada mata pelajaran penjasorkes, oleh karena itu akan dilakukan pengembangan model pembelajaran tematik integratif penjasorkes pada mata pelajaran IPA. Berdasarkan pernyataan di atas, maka akan dilakukan pengembangan lebih mendalam terhadap pelaksanaan model pembelajaran tematik integratif Penjasorkes pada mata pelajaran IPA di Sekolah dasar.

\section{RUANG LINGKUP}

Pendekatan saintifik (ilmiah) dalam pembelajaran dimaksudkan bahwa pembelajaran harus didasarkan pada fakta, bukan sekadar kira-kira. Dalam praktiknya, pembelajaran ini meliputi kegiatan mengamati, menanya, mengumpulkan informasi, menalar, menarik kesimpulan, mengomunikasikan. Kurikulum 2013 yang menggunakan tematik integratif dalam pembelajaran maka pada mata pelajaran penjasorkes perlu dikembangkan pembelajaran tematik integratif.

Batasan masalah dalam penelitian ini yaitu bagaimana mengembangkan model pembelajaran bagi siswa sekolah dasar yang mengintegrasikan mata pelajaran Penjasorkes dengan mata pelajaran IP dan apakah model pembelajaran tematik integratif Penjasorkes layak digunakan bagi siswa di sekolah dasar.

Tujuan dalam penelitian ini yaitu untuk mendeskripsikan cara mengembangkan model pembelajaran integratif Penjasorkes dengan pembelajaran pendidikan IPA di sekolah dasar dan menguji kelayakan model pembelajaran integratif Penjasorkes dengan pembelajaran pendidikan IPA di sekolah dasar.

\section{BAHAN DAN METODE}

Metode penelitian dan pengembangan atau dalam bahasa inggrisnya research and development adalah metode penelitian yang digunakan untuk menghasilkan produk tertentu, dan menguji keefektifan produk tersebut (Sugiyono, 2010). Melalui penelitian ini diharapkan dapat menjadi variasi penelitian yang lebih banyak menguji teori ke arah menghasilkan produk yang dapat digunakan dalam mengembangkan model pembelajaran tematik integrative Penjasorkes pada mata pelajaran IPA di sekolah dasar.

Model pembelajaran yang dikembangkan dalam penelitian dan pengembangan disini mengacu pada proses pembelajaran yang meliputi bertanya, menyelidiki solusi pemecahan, menghasilkan pengetahuan baru, mendiskusikan hasil penemuan dan pengalaman, dan merefleksikan penemuan baru yang ditemukan. Hasil belajar dan materi yang digunakan dalam model pembelajaran tematik integratif ini mengacu pada Standar Kompetensi (SK) dan Kompetensi Dasar (KD) untuk siswa sekolah dasar.

\subsection{Kajian Teori}

Ngalimun (2013) model pembelajaran adalah suatu perencanaan atau suatu pola yang digunakan sebagai pedoman dalam merencanakan pembelajaran di kelas, dengan kata lain model pembelajaran adalah suatu perencanaan atau pola yang dapat digunakan guru untuk mendesain pola-pola mengajar secara tatap muka didalam kelas.

Sesuai dengan pendapat Wang (2011) bahwa didalam pembelajaran physical education banyak tersirat konteks pendidikan moral seperti solidaritas, kerjasama dan kompetisi yang tersirat dalam interaksi antara guru dengan siswa dan antara siswa dengan siswa. Definisi lain mengenai pendidikan jasmani disampaikan

Ismael \& Hameed (2015) yang menyatakan bahwa "Physical education in school plays an important role in educating and developing students, attitudes and awareness towards sport as the student learn and practice sports in schools or in pastime will enable him to practice it in his daily life outside school". Pendidikan jasmani di sekolah berperan penting dalam mendidik dan mengembangkan sikap siswa serta kesadaran terhadap olahraga sebagai siswa belajar dan berlatih olahraga di sekolah atau hobi siswa akan memungkinkan untuk mempraktekkannya dalam kehidupan sehari-hari di luar sekolah.

IPA merupakan salah satu mata pelajaran pokok dalam kurikulum pendidikan di Indonesia, termasuk pada jenjang sekolah dasar. Menurut Susanto (2012) "Sikap ilmiah siswa dalam pembelajaran IPA dapat dikembangkan melalui kegiatan diskusi, percobaan, observasi, simulasi, atau kegiatan proyek di lapangan". Uraian tentang pengertian IPA tersebut, dapat disimpulkan bahwa ilmu pengetahuan alam merupakan pembelajaran berdasarkan pada prinsip-prinsip, proses yang dapat menumbuhkan sikap ilmiah siswa terhadap konsep-konsep IPA melalui pengamatan, diskusi dan penyelidikan sederhana.

\subsection{Metode Penelitian}

Metode penelitian yang digunakan yaitu research and development. Metode penelitian dan pengembangan atau dalam bahasa inggrisnya research and development adalah metode penelitian yang digunakan untuk menghasilkan produk tertentu, dan menguji keefektifan produk tersebut (Sugiyono, 2010).

Subjek coba dalam penelitian ini siswa sekolah dasar kelas IV, yaitu untuk uji coba skala kecil di SD N 02 Indralaya Utara, dan untuk uji coba skala besar penelitian 
dilakukan di SD N 11 dan SD N 13 Indralaya Utara. Pelaksanaan uji coba dengan skala kecil menggunakan subjek 20 siswa, dan subjek iji coba skala besarnya yaitu SD N 11 dan SD N 13 Indralaya Utara. Subjek uji coba dengan skala besar 45 siswa yaitu 23 dari SD N 11 dan 22 dari SD N 13 Indralaya Utara. Data yang dikumpulkan dari penelitian berupa data kuantitatif. Data kuantitatif diperoleh dari: (a) penilaian skala nilai validasi; (b) angket guru penjaskes; (c) angket respon siswa; (d) nilai tes pengetahuan.

Subjek dalam penelitian ini yaitu pada uji coba skala kecil menggunakan satu (1) sekolah dasar yang terdiri dari 1 guru penjasorkes dan 20 siswa, dan untuk uji coba skala besar menggunakan dua (2) sekolah dasar yang terdiri dari 2 orang guru penjasorkes dan 45 siswa.

\section{PEMBAHASAN}

Penelitian pengembangan model pembelajaran tematik integratif penjasorkes pada mata pelajaran IPA ini dilakukan dengan melalui langkah-langkah yang dimulai dari analisis kebutuhan, mengumpulkan informasi, mendesain produk, melakukan validasi para ahli, ujicoba skala kecil, melakukan revisi produk tahap awal, validasi ahli tahap kedua, ujicoba skala besar, revisi produk tahap akhir dan produk akhir pengembangan model pembelajaran. Langkah validasi ahli dilakukan dengan dua tahapan.Tahapan pertama dijadikan dasar sebagai peneliti untuk merevisi kekurangan-kekurangan yang ada pada model pembelajaran tematik integratif yang dikembangkan.

\subsection{Hasil Angket}

Prosedur pengembangan dalam penelitian pengembangan ini yaitu validasi dari ahli materi, kemudian setelah dinyatakan cukup layak, maka draf produk awal dapat diujicobakan pada skla kecil, selanjutnya direvisi lagi pada validasi ahli, kemudian diujicobakan lagi pada skala besar. Selanjutnya diberikan angket kepada guru sebagai partisi pada pengembangan ini, dengan guru pertama dengan persentase sebesar $82 \%$ dan guru kedua dengan persentase penilaian $80 \%$, sehingga didapat rata-rata angket guru sebesar $81 \%$, berikut ini hasil penilaian angket guru seperti tabel 1 .

Tabel 1. Hasil Angket Penilaian Guru

\begin{tabular}{|c|c|c|c|c|c|c|c|c|c|c|c|c|c|}
\hline \multirow[t]{2}{*}{$\mathrm{NO}$} & \multirow[t]{2}{*}{ Guru } & \multicolumn{10}{|c|}{ Pernyataan } & \multirow{2}{*}{$\begin{array}{l}\text { Nilai } \\
\text { Maks }\end{array}$} & \multirow{2}{*}{$(\%)$} \\
\hline & & 1 & 2 & 3 & 4 & 5 & 6 & 7 & 8 & 5 & 10 & & \\
\hline 1 & G1 & 4 & 4 & 4 & 4 & 4 & 4 & 4 & 4 & 2 & 5 & 50 & 82 \\
\hline 2 & $\mathrm{G} 2$ & 4 & 4 & 4 & 4 & 4 & 4 & 4 & 4 & 4 & 4 & 50 & 80 \\
\hline & Jumlah & & & & & & & & & & & 100 & 162 \\
\hline & $\overline{\boldsymbol{x}}$ & & & & & & & & & & & 50 & 81 \\
\hline
\end{tabular}

Setelah melakukan uji coba produk dengan skala kecil, maka peneliti kembali merevisi produk pembelajaran ini.
Setelah melakukan revisi maka didapat hasil validasi tahap 2 dari ahli materi pendidikan Jasmani dan Kesehatan.

Pada validasi tahap pertama persentase yang didapatkan 74\% dengan demikian dapat dinyatakan bahwa menurut ahli materi pendidikan jasmani dan kesehatan, pada tahap validasi pertama pengembangan model pembelajaran tematik integratif penjasorkes pada mata pelajaran IPA disekolah dasar dari aspek pendidikan jasmani dan kesehatan mendapatkan kategori "cukup layak".

Pada validasi tahap kedua persentase yang didapatkan $84 \%$ dengan demikian dapat dinyatakan bahwa menurut ahli materi sekolah dasar, pada tahap validasi kedua pengembangan model pembelajaran tematik integratif penjasorkes pada mata pelajaran IPA disekolah dasar dari aspek materi sekolah dasar mendapatkan kategori "Sangat layak".

Pada validasi tahap pertama persentase yang didapatkan 74\% dengan demikian dapat dinyatakan bahwa menurut ahli materi pendidikan jasmani dan kesehatan, pada tahap validasi pertama pengembangan model pembelajaran tematik integratif penjasorkes pada mata pelajaran IPA disekolah dasar dari aspek pendidikan jasmani dan kesehatan mendapatkan kategori "cukup layak", yang dapat dilihat dari

Tabel 2. Hasil PenghitungaValidasi Oleh Ahli Materi Penjaskes dan Sekolah Dasar

\begin{tabular}{|c|c|c|c|c|c|c|c|c|c|c|c|c|c|}
\hline $\begin{array}{c}\mathrm{N} \\
\mathrm{O}\end{array}$ & \multicolumn{10}{|c|}{ Ahli } & \multicolumn{10}{|c|}{ Pernyataan } & Nilai & \multirow{2}{*}{ Maks } & \\
\hline & & 1 & 2 & 3 & 4 & 5 & 6 & 7 & 8 & 9 & 10 & & \multirow{2}{*}{74} \\
\hline 1 & 1 & 4 & 4 & 4 & 3 & 4 & 4 & 3 & 5 & 3 & 3 & 50 & \\
\hline 1 & 1 & 5 & 4 & 5 & 4 & 4 & 4 & 4 & 4 & 5 & 3 & 50 & 84 \\
\hline
\end{tabular}

Pada validasi tahap kedua persentase yang didapatkan $84 \%$ dengan demikian dapat dinyatakan bahwa menurut ahli materi sekolah dasar, pada tahap validasi kedua pengembangan model pembelajaran tematik integratif penjasorkes pada mata pelajaran IPA disekolah dasar dari aspek materi sekolah dasar mendapatkan kategori "Sangat layak".

Uji coba skala besar untuk hasil angket guru penjaskes persentase yang didapatkan $81 \%$ dengan demikian dapat dinyatakan bahwa menurut guru, pada tahap uji coba skala besar pengembangan model pembelajaran tematik integratif penjasorkes pada mata pelajaran IPA disekolah dasar dari aspek guru penjasorkes masuk pada kategori " sangat layak".

Pada uji coba skala besar untuk hasil angket respon siswa persentase yang didapatkan. 
Tabel 3. Penghitungan Kategorisasi Angket Respon Siswa

\begin{tabular}{|l|l|l|l|l|l|l|l|l|l|l|l|}
\hline NO & Siswa & \multicolumn{7}{|c|}{ Jawaban Pernyataan } & \multicolumn{2}{c|}{$\begin{array}{l}\text { Nilai } \\
\text { maks }\end{array}$} & \multicolumn{2}{c|}{} \\
\hline & & 1 & 2 & 3 & 4 & 5 & 6 & 7 & 8 & & \\
\hline 1 & S1 & 5 & 4 & 4 & 4 & 3 & 4 & 5 & 4 & 40 & 77,5 \\
\hline 2 & S2 & 4 & 4 & 4 & 5 & 4 & 5 & 4 & 4 & 40 & 80 \\
\hline 3 & S3 & 4 & 4 & 4 & 3 & 4 & 4 & 3 & 4 & 40 & 75 \\
\hline 4 & S4 & 4 & 4 & 5 & 4 & 4 & 4 & 4 & 4 & 40 & 77,5 \\
\hline 5 & S5 & 5 & 4 & 5 & 4 & 4 & 4 & 4 & 4 & 40 & 80 \\
\hline 6 & S6 & 4 & 4 & 4 & 3 & 5 & 4 & 3 & 4 & 40 & 77,5 \\
\hline 7 & S7 & 5 & 4 & 5 & 4 & 4 & 4 & 4 & 4 & 40 & 85 \\
\hline 8 & S8 & 4 & 4 & 4 & 3 & 4 & 3 & 4 & 4 & 40 & 75 \\
\hline 9 & S9 & 4 & 4 & 4 & 3 & 5 & 4 & 3 & 4 & 40 & 77,5 \\
\hline 10 & S10 & 4 & 4 & 5 & 4 & 3 & 4 & 5 & 5 & 40 & 80 \\
\hline 45 & S45 & 5 & 4 & 5 & 4 & 4 & 4 & 4 & 4 & 40 & 80 \\
\hline & $\overline{\boldsymbol{x}}$ & & & & & & & & & 40 & 79,27 \\
\hline
\end{tabular}

Tabel di atas menunjukkan hasil angket respon siswa persentase yang didapatkan $79,27 \%$ dengan demikian dapat dinyatakan bahwa menurut siswa, pada tahap uji coba skala besar pengembangan model pembelajaran tematik integratif penjasorkes pada mata pelajaran IPA disekolah dasar dari angket respon siswa masuk pada kategori layak.

\subsection{Hasil Tes Pengetahuan Siswa}

Tabel 4 .Penghitungan Tes Pengetahuan Siswa

\begin{tabular}{|l|l|l|}
\hline NO & Siswa & Nilai Siswa \\
\hline 1 & S1 & 80 \\
\hline 2 & S2 & 80 \\
\hline 3 & S3 & 80 \\
\hline 4 & S4 & 80 \\
\hline 5 & S5 & 90 \\
\hline 6 & S6 & 80 \\
\hline 7 & S7 & 80 \\
\hline 8 & S8 & 100 \\
\hline 9 & S9 & 90 \\
\hline 10 & S10 & 90 \\
\hline 45 & S45 & 80 \\
\hline & Jumlah & 3880 \\
\hline & $\bar{x}$ & 86,2 \\
\hline
\end{tabular}

Pada uji coba skala besar untuk hasil tes pengetahuan siswa didapat rata-rata nilai yaitu 86,2 dengan demikian, hasil tes pengetahuan siswa sekolah dasar 86,2 sudah tuntas. Pada tahap uji coba skala besar pengembangan model pembelajaran tematik integratif penjasorkes pada mata pelajaran IPA disekolah dasar hasil tes pengetahuan siswa masuk dalam kate $\mu$ gori "sangat layak".

\subsection{Pembahasan Model Pembelajaran Tematik Integratif Penjasorkes Pada Mata Pelajaran IPA}

Penelitian pengembangan model pembelajaran tematik integratif penjasorkes pada mata pelajaran IPA ini dilakukan dengan langkah-langkah yang dimulai dari analisis kebutuhan, mengumpulkan informasi, mendesain produk, melakukan validasi para ahli, uji coba skala kecil, melakukan revisi produk tahap awal, validasi ahli tahap kedua, uji coba skala besar, revisi produk tahap akhir dan produk akhir pengembangan model pembelajaran. Langkah validasi ahli dilakukan dengan dua tahapan.Tahapan pertama dijadikan dasar sebagai peneliti untuk merevisi kekurangan-kekurangan yang ada pada model pembelajaran tematik integratif yang dikembangkan. Terdapat faktor-faktor lain yang mempengaruhi motivasi belajar siswa. Setelah melakukan uji coba skala kecil, dilakukan revisi lagi ke validasi ahli kemudian nilai yang didapat dari validasi pendidikan jasmani dan kesehatan mendapatkan persentase $74 \%$ masuk pada kategori "layak" dan ahli pendidikan IPA anak sekolah dasar dengan persentase mendapatkan pesentase sebesar 84\% sehingga masuk pada kategori "sangat layak". Dengan demikian berdasarkan revisi dari validasi ahli materi tersebut dapat dilakukan uji coba dengan skala besar.

Uji coba skala besar dilakukan dengan memberikan angket guru penjasorkes, angket respon siswa, dan tes pengentahuan siswa. Nilai rata-rata angket guru dari 2 sekolah yaitu sebesar $81 \%$ sehingga pada uji coba skala besar ini masuk pada kategori "sangat layak". Selanjutnya nilai rata-rata angket respon siswa dari 2 sekolah dasar yaitu sebesar 79,27\% sehingga masuk dalam kategori "layak". Hasil rata-rata tes pengetahuan 2 sekolah dasar yaitu sebesar 86,2 sehingga dalam proses belajar sudah tuntas dan masuk pada kategori "sangat layak", hasil tes pengetahuan menggunakan model pembelajaran tematik integratif selaras dengan pendapat Mulyasa (2014) menjelaskan bahwa kurikulum 2013 dapat dimaknai sebagai suatu konsep kurikulum yang menekankan pada pengembangan kemampuan melakukan tugas dengan kemampuan masingmasing, sehingga hasilnya dapat dirasakan oleh peserta didik. Dalam hal ini, pembelajaran tematik integratif sebagai salah satu sarana dalam mengembangkan kemampuan peserta didik memberikan kemudahan bagi peserta didik dalam memahami konsep materi yang tergabung dalam tema serta dapat menambah semangat belajar karena materi yang dipelajari merupakan materi yang nyata (kontekstual) dan bermakna bagi peserta didik.

\section{KESIMPULAN}

Berdasarkan pada tujuan penelitian dan pengembangan yang dilakukan dengan mengadopsi langkah pengembangan Borg \& Gall, yang diadopsi menjadi 9 langkah pengembangan. Model pembelajaran Penjasorkes dengan pembelajaran IPA berbentuk buku panduan praktis pengintegrasian dua materi pembelajaran yang layak 
digunakan. Buku panduan praktis model pembelajaran tematik integratif Penjasorkes terdiri dari; pendahuluan (latar belakang \& tujuan), penjelasan keterkaitan Penjasorkes dan pendidikan IPA, pelaksanaan model pembelajaran integratif, waktu dan tempat pelaksanaan model pembelajaran integratif penjasorkes, syntaxs (langkah-langkah), penilaian hasil belajar, penutup.

Model pembelajaran tematik integratif penjasorkes dengan pembelajaran IPA untuk siswa sekolah dasar berdasarkan validasi ahli materi Pendidikan Jasmani dengan persentase $74 \%$ masuk pada kategori "layak" dan ahli pendidikan IPA anak sekolah dasar dengan persentase mendapatkan pesentase sebesar $84 \%$ sehingga masuk pada kategori "sangat layak". Dengan demikian berdasarkan revisi dari validasi ahli materi tersebut dapat dilakukan uji coba dengan skala besar.

\section{SARAN}

Pemanfaatan produk yang dihasilkan dari pengembangan model pembelajaran yang dapat digunakan dalam pembelajaran pendidikan jasmani pada siswa sekolah dasar. Produk model permainan diperuntukkan kepada guru sebagai pemakai model pembelajaran. Aktivitas jasmani yang digunakan dalam pembelajaran penjasorkes dapat diaplikasikan dalam pembelajaran lain, seperti contoh: penjasorkes di integrasikan dengan IPA, kemudian dapat digunakan pada mata pelajaran lain seperti penjasorkes diintegrasikan dengan matematika, fisika bahkan agama.

Guru pendidikan jasmani olahraga dan kesehatan sekolah dasar sebagai pemakai produk pengembangan ini diharapkan dapat mengembangkan aktivitas jasmani sesuai dengan kreatifitas masing-masing yang tentunya menyesuaikan dengan karakteristik siswa dan keadaan lingkungan sekolah sekitar.

\section{DAFTAR PUSTAKA}

Husdarta \& Kusmaedi. 2013. Pertumbuhan dan perkembangan peserta didik olahraga dan kesehatan. Bandung: Alfabeta

Ismail.Al-oun Sood,, \& Hameed, Al-leheeby, MQ. 2015. Obstacles Facing The Implementation Of Physical Education Curriculum In Iraqi Public Schools As Perceived By Teacher In Anbar Governorate. Al al-Bayt University. Vol. 11. No. 16.

Joyce. Weil. \& Calhoun. 2009. Model of teaching Model Model Pembelajaran. Yogyakarta: Pustaka Pelajar.

Ken Ghanakan. 2013. The Integrated Learning Experience. William Carey Internasional Development. Jurnal. Vol 2 Issue I Winter.

Mulyasa. 2014. Pengembangan dan Implementasi Kurikulum 2013. Bandung: PT. Remaja Rosdakarya.

Ngalimun. 2013. Strategi dan Model Pembelajaran. Aswaja Pressindo. Yogyakarta

Rosdiani, Dini. 2012. Model Pembelajaran Langsung Dalam Pendidikan Jasmani dan Kesehatan. Bandung: Alfabeta.

Sugiyono. 2010. Metode Penelitian Pendidikan Pendekatan Kuantitatif, Kualitatif, dan R\&D. Bandung: ALFABETA.

Susanto, Ahmad. 2012. Teori Belajar dan Pembelajaran di Sekolah Dasar. Jakarta: Kencana Prenada Media Grup.

Trianto. 2014. Model Pembelajaran Terpadu. Jakarta: Bumi Aksara.

\section{UCAPAN TERIMA KASIH}

Terima kasih kepada Dekan FKIP Universitas Sriwijaya, Unit Penelitian dan Pengabdian pada Masyarakat, sehingga penelitian Sains, Teknologi, dan Seni FKIP Unsri dapat diselesaikan dengan baik. Dan terima kasih pada semua yang telah membantu sehingga penelitian ini dapat terselesaikan dengan baik. 